\title{
Standard germination test in physic nut (Jatropha curcas L.) seeds ${ }^{1}$
}

\author{
Glauter Lima Oliveira ${ }^{2}$, Denise Cunha Fernandes dos Santos Dias ${ }^{2 *}$, \\ Paulo Cesar Hilst ${ }^{2}$, Laércio Junio da Silva², Luiz Antônio dos Santos Dias ${ }^{2}$
}

\begin{abstract}
Defining adequate methods to assess seed germination is important to control the quality of commercial lots, especially for species that are not yet included in the Rules for Seed Testing. This study aimed to establish an adequate procedure for germination test in physic nut seeds (J. curcas L.). Three seed lots, in eight replications of 25 seeds each, were sown on paper towel rolls moistened with a water volume equivalent to 2.7 the weight of the dry paper and in sterilized sand moistened up to $60 \%$ of its water-holding capacity. The seeds of each treatment were maintained on germination chambers at temperatures of $20,25,30$ and $20-30^{\circ} \mathrm{C}$. Daily counts were made to define the ideal date to perform the first and the last count test. Criteria for classifying seedlings as normal and abnormal were also established. The experiment was conducted in a completely randomized design in a split plot arrangement, and the means were compared by Tukey's test $(\mathrm{P}<0.05)$. For maximum germination potential of physic nut seeds, the germination test should be conducted at $25{ }^{\circ} \mathrm{C}$ and $30{ }^{\circ} \mathrm{C}$, using sand or paper towel as a substrate, with the counts at 7 and 12 days after sowing.
\end{abstract}

Index terms: viability, methodology, seeds, physic nut.

\section{Teste de germinação em sementes de pinhão manso (Jatropha curcas L.)}

RESUMO - Estabelecer procedimento adequado para a condução do teste de germinação com espécies que ainda não constam nas Regras para Análise de Sementes é de grande importância para viabilizar a certificação e comercialização de lotes. Objetivou-se estabelecer metodologia para a condução do teste de germinação em sementes de pinhão manso (J. curcas L.). Sementes de três lotes, em oito repetições de 25, foram semeadas nos seguintes substratos: rolo de papel toalha umedecido com volume de água equivalente a 2,7 vezes o peso do papel seco, confeccionando-se rolos; areia esterilizada e umedecida até $60 \%$ da sua capacidade de retenção (entre areia). As sementes foram mantidas em germinadores nas temperaturas de $20,25,30{ }^{\circ} \mathrm{C}$ e $20-30{ }^{\circ} \mathrm{C}$, realizando-se contagens diárias para definir a data ideal para as avaliações do teste. Foram estabelecidos também critérios para a classificação das plântulas como normais e anormais. O experimento foi conduzido em DIC, em esquema de parcela subdividida. As médias dos tratamentos foram comparadas pelo teste de Tukey $(\mathrm{P}<0,05)$. Para a obtenção do potencial máximo de germinação das sementes de pinhão manso, o teste de germinação deve ser conduzido nas temperaturas de $25^{\circ} \mathrm{C}$ ou $30^{\circ} \mathrm{C}$, utilizando-se semeadura entre areia ou em rolo de papel, com contagens aos 7 e 12 dias após a semeadura.

Termos para indexação: viabilidade, metodologia, sementes, pinhão manso.

\section{Introduction}

Physic nut (Jatropha curcas L.) is an oilseed crop that belongs to the Euphorbiaceae family, and it has properties that are suitable for biodiesel production (Tiwari et al., 2007; Dias, 2011). The crop is mainly propagated by seeds collected from mother plants selected by producers, but they are marketed without a strict quality control, because there is still not an organized system in Brazil for producing and marketing these seeds (Silva et al., 2012).

Considering the demand for plant propagation material for the establishment of physic nut crops, the Ministry of Agriculture (MAPA), through the normative instruction number 4 , of $01 / 14 / 2008$, authorized the registration of the species Jatropha curcas L. on the National Register of Cultivars (RNC) without the requirement for a minimum supply of propagation material to be made available by a natural person or entity. Moreover, the seeds can be marketed on condition that the Statement of Commitment and Responsibility has been signed between seed producers and farmers. This statement will be required until standards

${ }^{1}$ Submitted on 08/18/2014. Accepted for publication on 09/04/2014.

${ }^{2}$ Departamento de Fitotecnia, Universidade Federal de Viçosa, 36570-000 - Viçosa, MG, Brasil.

*Corresponding author $<$ dcdias@ufv.br>

Journal of Seed Science, v.36, n.3, p.336-343, 2014 
for identification and quality of the propagation material have been established (Brasil, 2008). Currently, there is no official standard for marketing physic nut seeds according to Normative Instruction number 45 of 09/17/2013 (Brasil, 2013), which sets standards for producing and marketing seeds of various crops. In addition, there is no information in the Rules for Seed Testing (Brasil, 2009) on conducting germination tests with seeds of physic nut.

In this context, standardized methods should be established for seed quality assessment to enable quality control of marketed lots (Silva et al., 2008; Pinto et al., 2009; Pascuali et al., 2012). The germination test is one of these methods. It must be carried out under controlled conditions so as to ensure standardization and reproducibility of results, which are optimum for the species. In this test, factors such as temperature, humidity, substrate and seeding method greatly influence the results, which should express the maximum potential germination of the lot (Marcos-Filho, 2005).

Information on the ideal conditions for the germination of physic nut seeds are not conclusive. Fogaça et al. (2007) found higher values for germination under the following conditions: sowing in sand under alternating temperature of $20-30{ }^{\circ} \mathrm{C}$, with an 8 -hour photoperiod or sowing in vermiculite or on paper roll, at 30 ${ }^{\circ} \mathrm{C}$. This temperature was also ideal for seed germination both for seeding in sand or on paper roll. There was no germination below $20{ }^{\circ} \mathrm{C}$, or at $45^{\circ} \mathrm{C}$ or above (Dias et al., 2007), while for Martins et al. (2008), the germination test for physic nut seeds should be performed in sand and under alternating temperatures of $20-30{ }^{\circ} \mathrm{C}$. In contrast, Neves et al. (2009) observed higher germination at 25 and $30{ }^{\circ} \mathrm{C}$ compared with 20 and $20-30{ }^{\circ} \mathrm{C}$. Temperatures of $25^{\circ} \mathrm{C}$ or 20-30 ${ }^{\circ} \mathrm{C}$ were the most suitable for seed germination on paper substrate with final counting at 12 days after sowing (Vanzolini et al., 2010). More recently, Pascuali et al. (2012), when evaluating different temperatures and substrates for germination, found higher germination at $30^{\circ} \mathrm{C}$ in sand substrate and in the absence of light. However, Nobre et al. (2007) found higher germination at $30^{\circ} \mathrm{C}$ or at $20-30{ }^{\circ} \mathrm{C}$ under light.

Defining criteria for seedling assessment is also important when it aims to establish an appropriate methodology for the germination test. In this sense, there are few studies on the characterization of post-seminal development of physic nut.

The purpose of this study was to establish appropriate methodology for conducting the standard germination test of physic nut seeds.

\section{Material and Methods}

The research was conducted in the Seed Laboratory in the Department of Plant Science, Federal University of Viçosa, and used three lots of physic nut seeds with initial moisture content of approximately $8.5 \%$, as determined by the oven method at $105 \pm 3^{\circ} \mathrm{C}$, for 24 hours (Brasil, 2009).

The seeds of each lot were submitted to the germination test using eight replicates of 25 seeds, with the substrates and sowing methods described below:

Germination test on paper roll: seeds were distributed on two sheets of paper towel, sterilized in an oven at $120^{\circ} \mathrm{C}$ for an hour, and moistened with water equivalent to 2.7 times the weight of the dry substrate, according to the results obtained in preliminary tests. Then, the seeds were covered with a sheet of paper and rolled up. Germination test in sand: $1500 \mathrm{~mL}$ polypropylene boxes were used; they contained sand that was washed, sterilized and moistened until $60 \%$ water-holding capacity, according to Brasil (2009). Sowing was done about $1.5 \mathrm{~cm}$ deep.

After sowing, each treatment described above was kept in germinators at temperatures of $20,25,30^{\circ} \mathrm{C}$ and $20-30{ }^{\circ} \mathrm{C}(16 \mathrm{~h}$ at $20^{\circ} \mathrm{C}$ and $8 \mathrm{~h}$ at $30^{\circ} \mathrm{C}$, every $24 \mathrm{~h}$ ) under light for eight hours a day. Daily counts were performed of the number of normal seedlings obtained each day to determine the accumulated germination curves, so as to identify the best times to perform the first and second counts. Seedlings were also illustrated and criteria were established for classifying them as normal or abnormal. The following evaluations were made:

Germination percentage: consisted of the number of seedlings characterized as normal obtained at 10 and 12 days after sowing; values are expressed in percentage terms. First count of germination test: represented by the number of normal seedlings obtained at 5 and 7 days after start of the germination test, and results were expressed in percentage terms. Dates for counts were based on data obtained for the curves of accumulated germination. Germination rate (GR) and Germination Rate Index (GRI): were conducted together with the germination test; daily counts were made of the number of normal seedlings until stabilization of counts. GR (days) and GRI (seedlings.day ${ }^{-1}$ ) were calculated according to Nakagawa (1999). Seedling dry matter (DM): normal seedlings obtained after each count of the germination test were dried in a forced air circulation oven, at $60 \pm 2{ }^{\circ} \mathrm{C}$, until constant weight. The results were expressed in g.seedling ${ }^{-1}$.

The experiment was conducted in a completely randomized design with four replications. The data underwent the Shapiro-Wilk normality test. Then, they underwent analysis of variance in a split plot design: the plots contained the temperatures $\left(20,25,30\right.$ and $\left.20-30{ }^{\circ} \mathrm{C}\right)$ and the substrates (paper towel and sand), and the subplots were comprised of the assessment times $(5,7,10$ and 12 days) of the germination test. The means for the temperature factor were compared by Tukey's test $(p<0.05 \%)$, and the mean of factors substrate and 
assessment times, by the F-test $(p<0.05 \%)$. Data analysis was performed using the SAS software (SAS, 2009).

\section{Results and Discussion}

Figure 1 shows the comparison of the substrates. For the three lots, higher values of germination and germination first count were obtained when using sand at temperatures of 25 and $30{ }^{\circ} \mathrm{C}$, while the temperature of $20^{\circ} \mathrm{C}$ and $20-30{ }^{\circ} \mathrm{C}$ generally resulted in higher germination on the paper roll.

For germination temperatures (Figure 1), for the three lots which used the sand substrate, higher germination potential and first germination count occurred at 25 and 30 ${ }^{\circ} \mathrm{C}$, while on paper roll, values obtained for these variables at 25,30 and $20-30{ }^{\circ} \mathrm{C}$ did not differ and were higher than those observed at $20^{\circ} \mathrm{C}$. The lower values for both germination and first count were obtained at $20^{\circ} \mathrm{C}$, regardless of substrate. The lower germination observed in tests conducted at $20{ }^{\circ} \mathrm{C}$ can be attributed to the low metabolic activity of seeds at a lower temperature (Socolowski and Takaki, 2004;. Bewley et al, 2013), resulting in a lower percentage of normal seedlings at the end of the test.

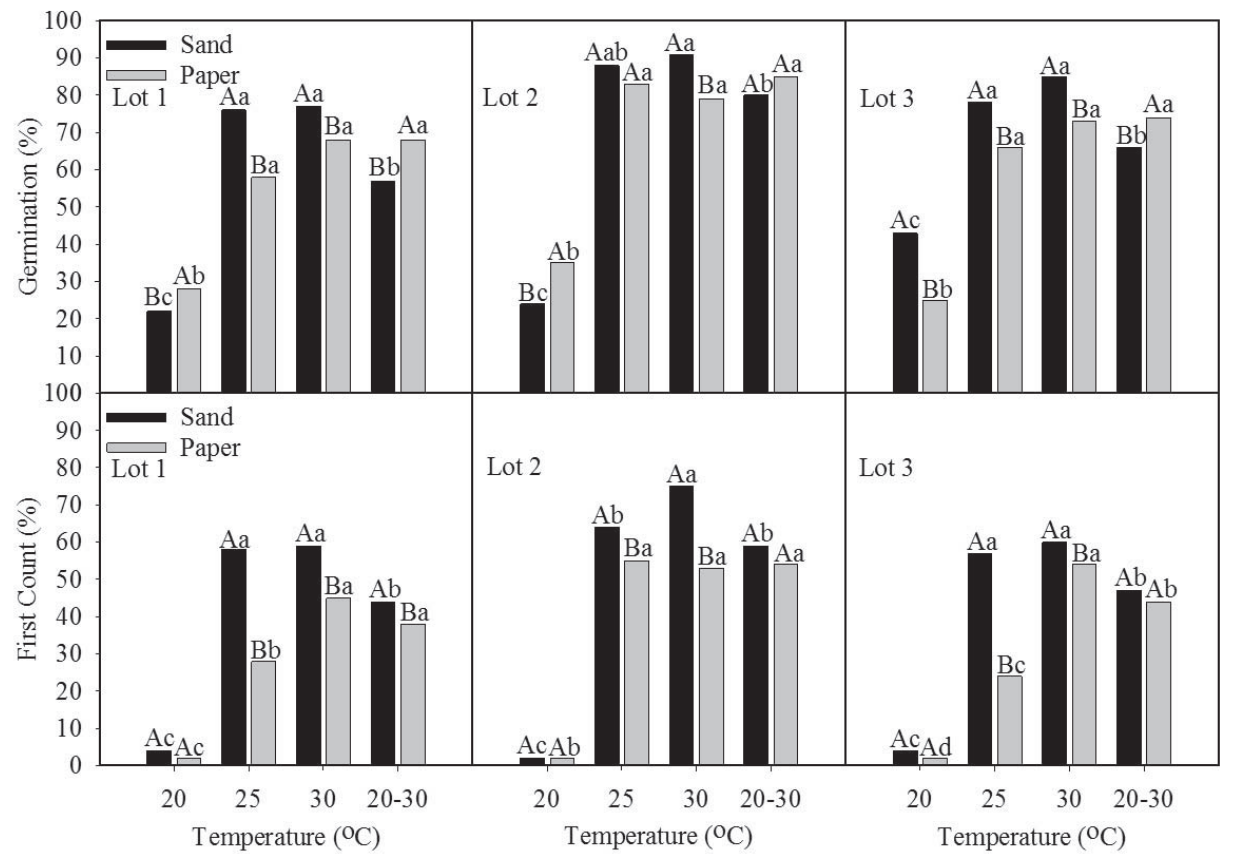

Figure 1. Mean values of germination percentage and first germination count of three lots of $J$. curcas L. in sand and on paper roll under different temperatures.

*Capital letters compare substrates at each temperature $(\mathrm{F}, p<0.05)$.

*Lowercase letters compare the temperatures in each substrate (Tukey, $p<0.05$ ).

The temperature of $25^{\circ} \mathrm{C}$ was recommended for conducting the germination test of physic nut seeds in sand and on paper roll by Neves et al.(2009) and Vanzolini et al. (2010). However, Fogaça et al. (2007) observed that the maximum values of germination were not found at this temperature, which was also observed by Martins et al. (2008), and ranging the temperature between 20 and $30{ }^{\circ} \mathrm{C}$ best expressed seed germination, both in sand and on paper. In contrast, Dias et al. (2007), found higher values when the germination test was conducted at 30 and 35 ${ }^{\circ} \mathrm{C}$. These authors also reported that physic nut seeds did not germinate at temperatures below $20{ }^{\circ} \mathrm{C}$ or above $45^{\circ} \mathrm{C}$. These results reinforce that, to date, there is no consensus as to the most suitable temperature for the germination of these seeds.
Figure 2 shows that a lower germination rate was obtained at $20{ }^{\circ} \mathrm{C}$ for all lots, a result which confirms the worse performance of the seeds at this temperature. According to Godoi and Takaki (2005), temperature affects water absorption rate, and according to Höes et al. (2004) and Bewley et al. (2013), it also affects the biochemical reactions that regulate the metabolism of the germination process. Therefore, it affects both the rate and uniformity of germination and total germination. According to Carvalho and Nakagawa (2012), germination occurs only within certain limits of temperature, and there is an optimum temperature at which the process occurs with maximum efficiency, yielding maximum germination in the shortest possible period. 


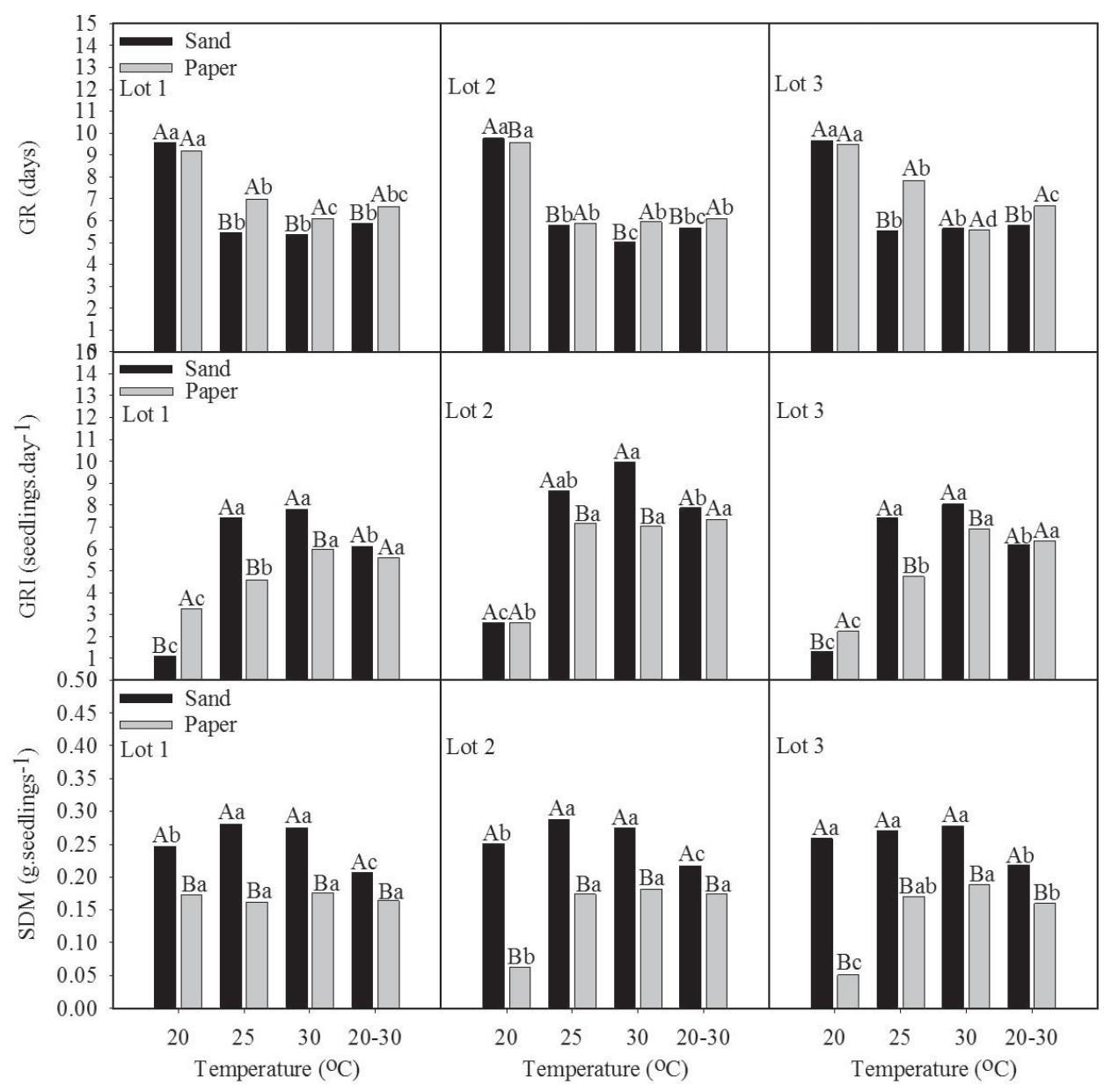

Figure 2. Mean values of germination rate (GR), germination rate index (GRI) and seedling dry matter (SDM) of three lots of $J$. curcas L. in sand and on paper roll, under different temperatures.

*Capital letters compare substrates at each temperature $(\mathrm{F}, p<0.05)$.

*Lowercase letters compare temperatures in each substrate (Tukey, $p<0.05$ ).

As observed in the germination test (Figure 1), a higher germination rate (Figure 2), both by GRI and GR, was obtained at 25 and $30{ }^{\circ} \mathrm{C}$ in the sand substrate. In general, a lower germination rate was observed at $20{ }^{\circ} \mathrm{C}$, with no significant difference in GR between the substrates for lots 1 and 3 . Neves et al. (2009) also observed a reduction in the germination rate index in physic nut seeds germinated at $20^{\circ} \mathrm{C}$.

In general, it is observed that the physic nut seeds from the three lots expressed their maximum germination potential at 25 and $30^{\circ} \mathrm{C}$ in sand, where values were greater than those for paper roll (Figure 1). It was also observed that both GRI (Figure 2) and DM (Figure 3) were higher at 25 and $30{ }^{\circ} \mathrm{C}$ also in sand substrate. Similar results were found by Martins et al. (2008). Importantly, there was higher contamination by microorganisms on paper roll than in sand, which explains the higher values of germination in the latter substrate. There is no direct contact between substrate and seedling throughout the test in sand, as opposed to paper roll. Thus, seedlings may be able to avoid microorganisms that can affect their development, resulting in higher germination.

However, the advantages of using the paper substrate over sand should be taken into account: for example, ease of test setup, less space used in the germinators, and no need for sterilization.

The substrate is a physical medium whose purpose is to maintain the right conditions for germination and seedling development. According to Martins et al. (2008), the substrate directly affects germination and, hence, germination rate, because of its structure, aeration, water holding capacity, degree of pathogen infestation, among others; thus, it may or may not increase the rate and percentage of seed germination.

The highest rates of seedling dry matter (Figure 2) were observed at 25 and $30{ }^{\circ} \mathrm{C}$ in the sand substrate, possibly because this substrate allows better seedling development after germination compared with the paper roll, which poses some physical restraint to seedling growth. At all temperatures, there 
was a higher development of seedlings in sand. Seedling growth influences the definition of times for performing the first and final count of the germination test, and also the interpretation of the test results, because seedlings should reach a minimum level of development so that their basic structures can be assessed and they can be classified as normal or abnormal.

Figure 3 shows the seedlings characterized as normal. These seedlings have a well-developed hypocotyl, and their root system comprises a well developed taproot and four basal roots in its periphery, or a short taproot with well-developed basal roots. Considering the criteria for abnormality of seedlings established by RST (Brasil, 2009), abnormal seedlings were considered as such when they showed atrophy of the entire root system, stunted and necrotic root, negative geotropism, twisting or folding of the hypocotyl, short and thick hypocotyl, damage at the point where the hypocotyl connects with the endosperm, and seeds in early germination without characterizing a seedling (Figure 4).
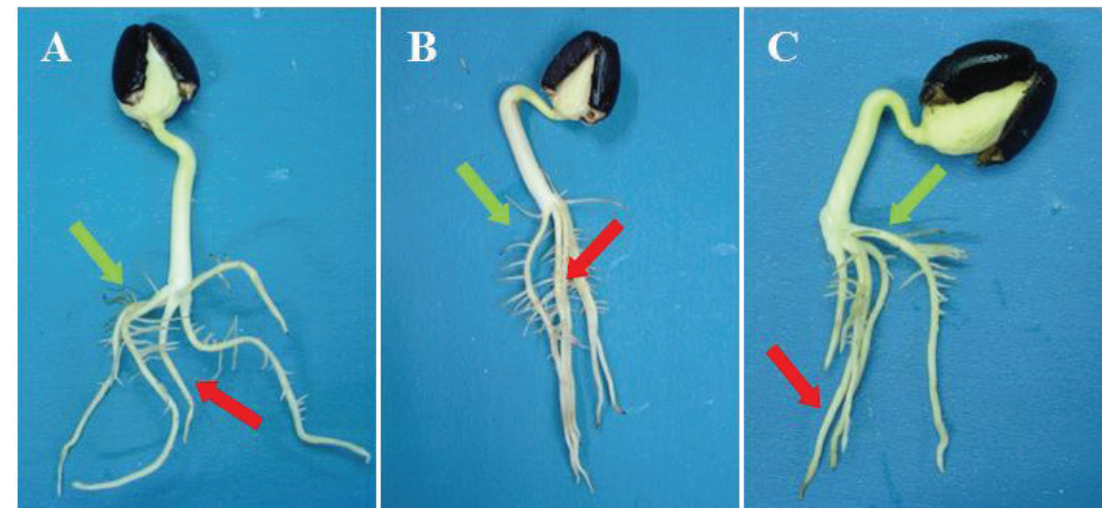

Figure 3. Structural characteristics of normal seedlings of J. curcas L.: A, B, C - well-developed hypocotyl and root system comprised of a well developed root (red arrow) and four secondary roots in its periphery (green arrow).

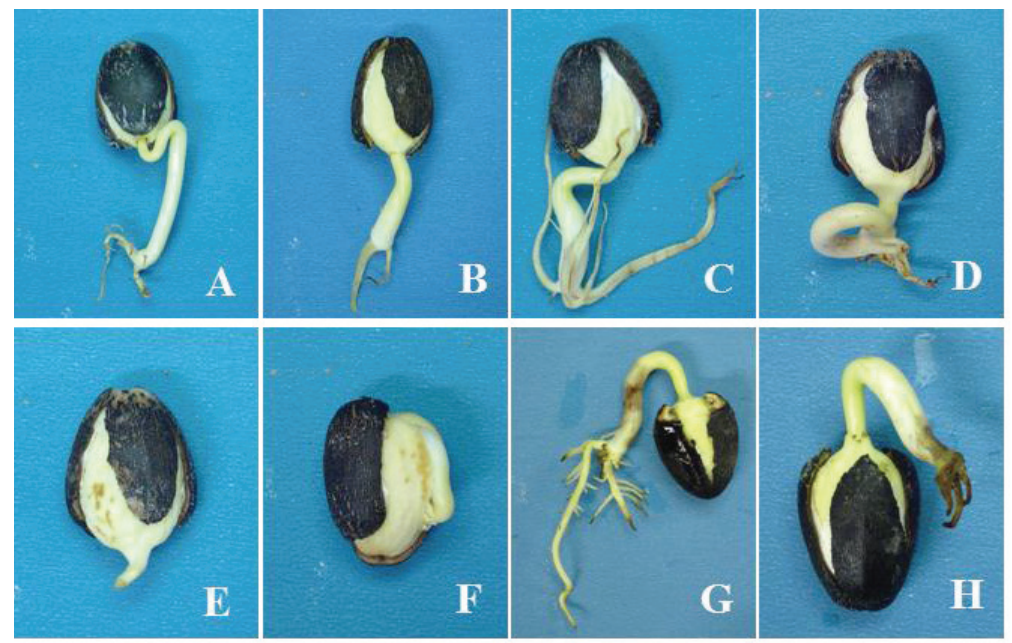

Figure 4. Structural characteristics of abnormal seedlings of J. curcas L.: A, B - stunted root; C- negative geotropism; D twisted hypocotyl and stunted root system; E, F - seed in early germination without characterizing a seedling; G infected seedling; $\mathrm{H}$ - stunted and necrotic root system.

The data collected from the daily assessment of germination enabled the design of cumulative germination curves for each treatment (Figure 5). From the third day of conducting the test it was observed the appearance of normal seedlings stabilizing between the tenth and twelfth day following the start of the test suggest most if not already normal seedlings, leaving only non-germinated seeds, which have been classified how hard (did not absorb water) or dead (loose seeds and attacked by microorganisms, according to Brasil (2009).

Five days after sowing (Figure 5), it is also observed, for most treatments, that the values obtained for normal seedlings 
were below $50 \%$, and the seedlings were not very developed yet, while on the seventh day, in the germination tests in sand at 25,30 and $20-30{ }^{\circ} \mathrm{C}$ and on paper at 30 and $20-30{ }^{\circ} \mathrm{C}$, the percentage of normal seedlings was above $50 \%$. A different behavior was observed at $20{ }^{\circ} \mathrm{C}$, in both substrates. Some seedlings were still underdeveloped and it was difficult to classify them as normal at both 10 and 12 days after sowing.

These results in both Figures 5 and 6 reinforce the periods of 7 and 12 days as the most appropriate for performing the first and final germination count for physic nut seeds. Figure 6 shows
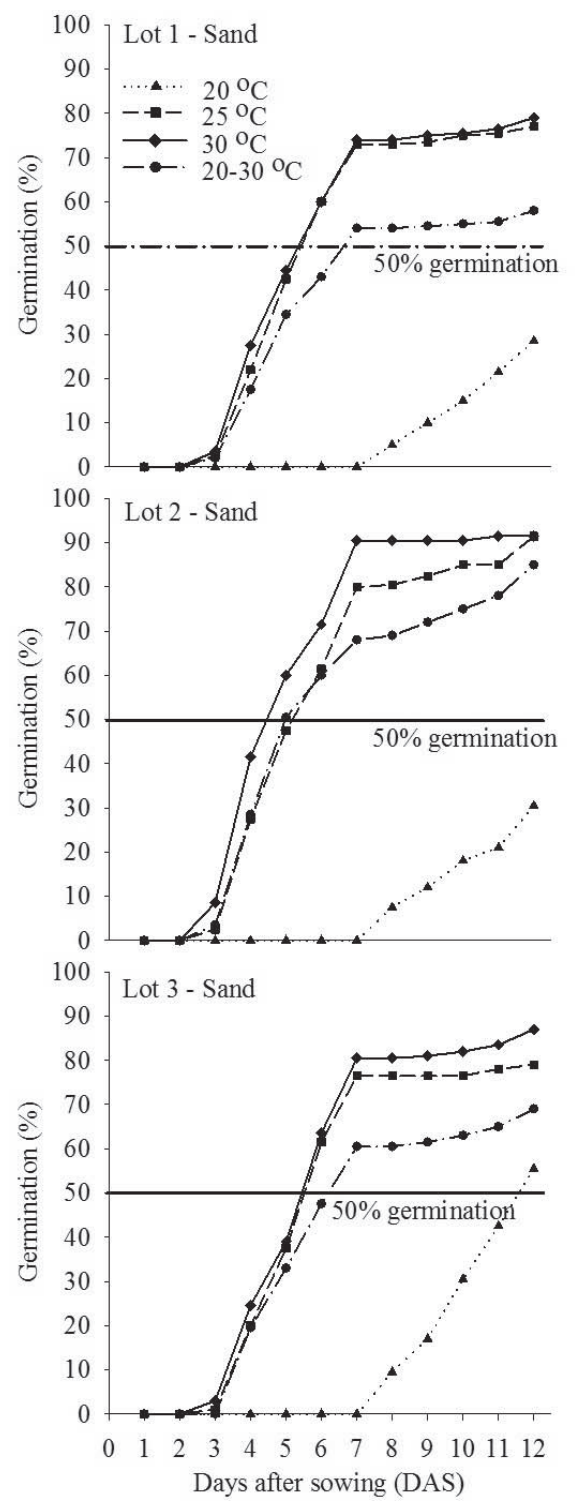

that the temperature of $20^{\circ} \mathrm{C}$ resulted in the worst performances in both count periods. Higher germination percentage was obtained in tests conducted at temperatures of 25, 30 and 20$30{ }^{\circ} \mathrm{C}$, with counts performed at 7 (first count) and 12 (final count) days after sowing. Comparing these results with those of germination (Figure 1), where the temperatures were compared within each substrate, higher values of germination at 25 and $30{ }^{\circ} \mathrm{C}$ were observed in sand for the three lots. On the paper roll, there was no significant difference between germination at temperatures of 25,30 and $20-30{ }^{\circ} \mathrm{C}$.
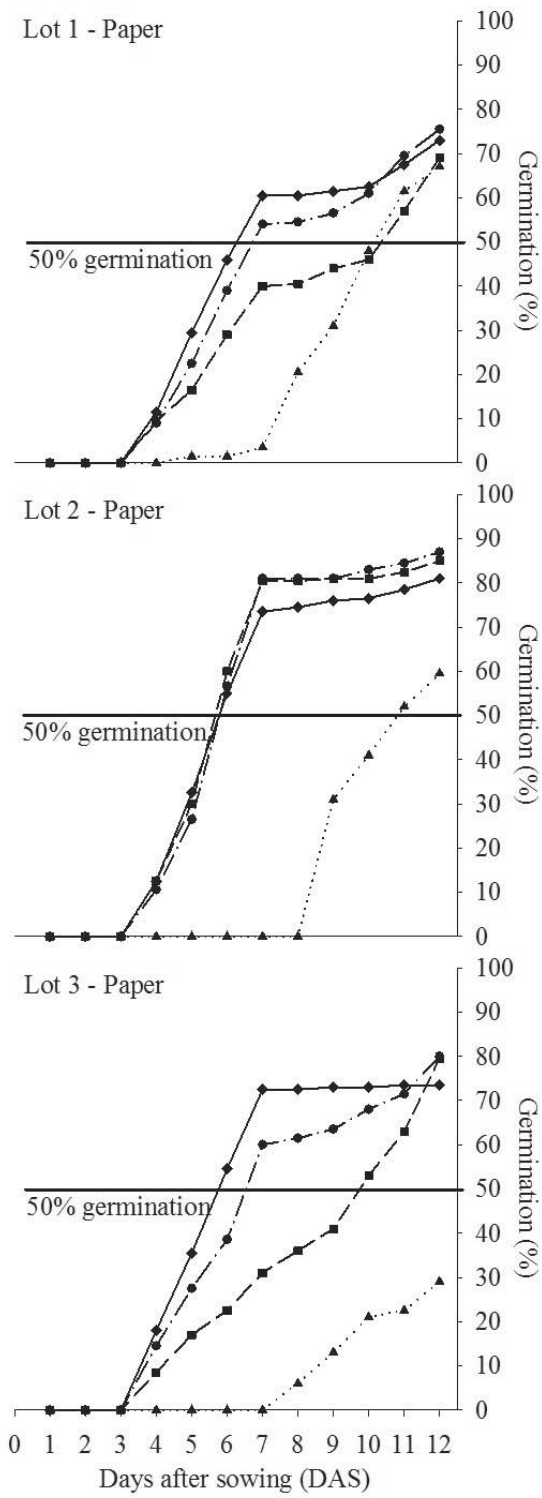

Figure 5. Cumulative germination of three lots of $J$. curcas L. in sand and on paper roll under different temperatures.

To date, there is no consensus in the literature regarding the most appropriate time for assessing the seed germination test with this crop. According to Martins et al. (2008), the first count and the final count of germination in physic nut seeds should be performed at 5 and 10 days after sowing, respectively. Similar results were found by Silva et al. 
(2008) who recommended using the temperature of $30{ }^{\circ} \mathrm{C}$, on paper roll, with final count at 10 days after sowing, while Neves et al. (2009) indicated the 10th and 15th days are suitable for the first and final count of the germination test. The results obtained in this study showed that evaluations of the test must be made at 7 and 12 days after sowing, since there was stabilization of scores from the 12th day, and there was increased occurrence of microorganisms with the seedlings remaining on the paper roll for a few more days.

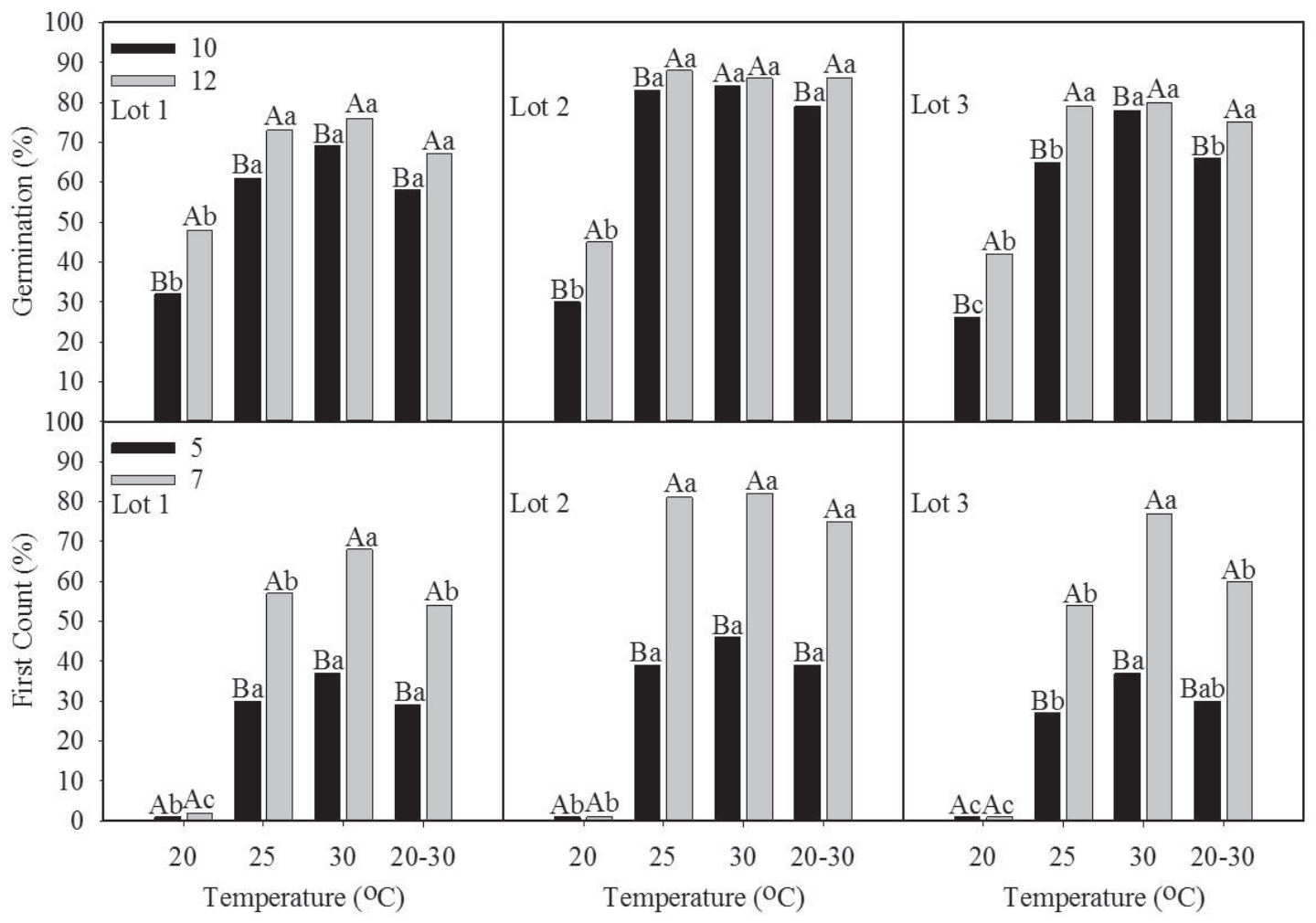

Figure 6. Mean values of germination at 10 and 12 days after sowing, and first germination count, at 5 and 7 days after sowing, obtained for the three seed lots of $J$. curcas L. at different temperatures.

*Capital letters compare assessment times at each temperature (F, $p<0.05)$.

*Lowercase letters compare temperatures at each assessment time (Tukey, $p<0,05$ ).

\section{Conclusions}

For physic nut seeds, the germination test should be conducted at temperatures of $25^{\circ} \mathrm{C}$ or $30^{\circ} \mathrm{C}$, with seeding in sand or paper roll.

The first and final count of the germination test should be performed at 7 and 12 days after sowing, respectively.

\section{Acknowledgments}

The authors are thankful to CNPq and FAPEMIG for their financial support and the graduate research grant given to the first author.

\section{References}

BEWLEY, J. D.; BRADFORD, K. J.; HILROST, H. W. M.; NONOGAKI, H Seeds: physiology of development, germination and dormancy. 3 ed., New York: Springer, 381p. 2013.

BRASIL. Instrução normativa ${ }^{\circ}$ 4, de 14 de janeiro de 2008. Diário Oficial da União, Ministério da Agricultura, Pecuária e Abastecimento, Brasília, DF, 15 jan. 2008 , Seção I, p.4.

BRASIL. Instrução normativa $n^{\circ} 45$, de 17 de setembro de 2013. Diário Oficial da União, Ministério da Agricultura, Pecuária e Abastecimento, Brasília, DF, 18 set. 2013, Seção I, p.16.

BRASIL. Ministério da Agricultura, Pecuária e Abastecimento. Regras para análise de sementes. Ministério da Agricultura, Pecuária e Abastecimento. Secretaria de Defesa Agropecuária. Brasília: MAPA/ACS, 2009. 395p. http:// www.agricultura.gov.br/arq_editor/file/2946_regras_analise_sementes.pdf

CARVALHO, N.M.; NAKAGAWA, J. Sementes: ciência, tecnologia e produção. 5 ed. Jaboticabal: FUNEP, 590 p. 2012. 
DIAS, L.A.S. Biofuel plant species and the contribution of genetic improvement. Crop Breeding and Applied Biotechnology, v.1, p.16-26, 2011. http://dx.doi.org/10.1590/S1984-70332011000500004

DIAS, M.P.; DIAS, D.C.F.S.; DIAS, L.A.S. Germinação de sementes de pinhão manso (Jatropha curcas L.) em diferentes temperaturas e substratos. In: II Congresso da Rede Brasileira de Tecnologia de Biodiesel, 2007, Brasília. Anais do II Congresso da Rede Brasileira de Tecnologia de Biodiesel. Brasília: MCT/ABIPIT, p. 1-5, 2007.

FOGAÇA, C.A.; SILVA, L.L; POLIDORO, J.C.; BREIER, T.B.; LELES, P. S.S. Metodologia para a condução do teste de germinação em sementes de Jatropha curcas L. In: $4^{\circ}$ Congresso Brasileiro de Plantas Oleaginosas, Óleos, Gorduras e Biodiesel. Anais. Varginha, p.1351-1357, 2007. http://oleo.ufla. br/anais_04/artigos/pdfs/a4206.pdf

GODOI, S.; TAKAKI, M. Efeito da temperatura e a participação do fitocromo no controle da germinação de sementes de embaúba. Revista Brasileira de Sementes, v.27, n.2, p.87-90, 2005. http://dx.doi.org/10.1590/S010131222005000200013

HÖES, A.; SCHULCH, L.O.B.; PESKE, S.T.; BARROS, A.C.S.A. Emergência e crescimento de plantulas de arroz em resposta à qualidade fisiológica de sementes. Revista Brasileira de Sementes, v.26, n.1, p.92-97, 2004. http://dx.doi.org/10.1590/S0101-31222004000100014

MARCOS- FILHO, J. Fisiologia de sementes de plantas cultivadas. FEALQ: Piracicaba, 2005. 495p

MARTINS, C.C.; MACHADO, C.G.; CAVASINI, R. Temperatura e substrato para o teste de germinação de sementes de pinhão manso. Revista Ciência e Agrotecnologia, v.32, n.3, p.863-868, 2008. http://dx.doi.org/10.1590/S141370542008000300024

NAKAGAWA, J. Testes de vigor baseados no desempenho das plântulas. In: KRZYZANOWSKI, F.C.; VIEIRA, R.D.; FRANÇA-NETO, J.B. (Ed.). Vigor de sementes: conceitos e testes. Londrina: ABRATES, Cap.2, p.1-21, 1999.

NEVES, J.M.G.; SILVA, H.P.; BRANDÃO-JÚNIOR, D.S; MARTINS, E.R.; NUNES, U.R. Padronização do teste de germinação para sementes de pinhão-manso. Revista Caatinga, v.22, n.4, p.76-80, 2009. http://periodicos. ufersa.edu.br/revistas/index.php/sistema/article/view/1262
NOBRE, D.A.C; ANDRADE, J.A.; DAVID, A.M.S.; RESENDE, J.C.F.; FARIA, M.A.V.R.; DAVID, D.A. Germinação de sementes de pinhãomanso submetidas a diferentes condições de temperaturas. In: $4^{\circ}$ Congresso Brasileiro de Plantas Oleaginosas, Óleos, Gorduras e Biodiesel. Anais. Varginha, p.1119- 1126, 2007.

PASCUALI, L.C.; SILVA, F.S.; PORTO, A.G.; SILVA FILHO, A.; MENEGHELLO, G.E. Germinação de sementes de pinhão manso em diferentes temperaturas, luz e substratos. Semina: Ciências Agrárias, v.33, n.4, p.1435-1440, 2012. http://dx.doi.org/10.5433/1679-0359.2012v33n4p1435

PINTO, T.L.F.; MARCOS FILHO, J.; FORTI, V.A.; CARVALHO, C.D.; GOMES JUNIOR, F.G. Avaliação da viabilidade de sementes de pinhão manso pelos testes de tetrazólio e de raios X. Revista Brasileira de Sementes, v.31, n.2, p.195-201, 2009. http://dx.doi.org/10.1590/S0101-31222009000200023

SAS- Program SAS - Getting started with the SAS Learning Edition. North Carolina: Cary SAS Publishing, 2009, 200p.

SILVA, H.P.; NEVES, J.M.G.; BRANDÃO JUNIOR, D.S.; COSTA, C.A. Quantidade de água do substrato na germinação e vigor de sementes de pinhão-manso. Revista Caatinga, v.21, n.5, p.178-184, 2008. http:// periodicos.ufersa.edu.br/revistas/index.php/sistema/article/view/666

SILVA, L.J.; DIAS, D.C.F.S.; MILAGRES, C.C.; DIAS, L.A.S. Relationship between fruit maturation stage and physiological quality of physic nut (Jatropha curcas L.) seeds. Revista Ciência e Agrotecnologia, v.36, n.1, p.3944, 2012. http://dx.doi.org/10.1590/S1413-70542012000100005

SOCOLOWSKI, F.; TAKAKI, M. Germination of Jacaranda mimosifolia (D. Don-Bignoniaceae) seeds: effects of light, temperature and water stress. Brazilian Archives of Biology and Technology, v.47, p.785-792, 2004. http:// dx.doi.org/10.1590/S1516-89132004000500014

TIWARI, A.K.; KUMAR, A.; RAHEMAN, H. Biodiesel production from jatropha oil (Jatropha curcas) with high free fatty acids: An optimized process. Biomass and Bioenergy, v.31, n.8, p.569-575, 2007. http://dx.doi. org/10.1016/j.biombioe.2007.03.003

VANZOLINI, S.; MEORIN, E.B.K.; SILVA, R.A.; NAKAGAWA, J Qualidade sanitária e germinação de sementes de pinhão-manso. Revista Brasileira de Sementes, v.32, n.4, p.9-14, 2010. http://dx.doi.org/10.1590/ S0101-31222010000400001 